\title{
THE HISTORY OF THE NAVAL MESS (UNION HOTEL) PRETORIA
}

\author{
S/Lt J.D. Bredenkamp*
}

\section{Introduction}

Naval Headquarters moved from Simonstown to Pretoria in January 1977. The then SA Naval Headquarters Unit was there 'to support the Chief of the Navy and his five Chiefs of Naval Staff and their Staff Officers in matters pertaining to personnel, administration, operations, logistics, intelligence and finance as well as most naval matters related to the inland area'. During the period 1977 to 1979 , members of the HQ Unit were accommodated in mainly the Air Force Officers and NCO Messes till the Union Hotel was purchased in 1979.

Under the guidance of the present officer commanding - Commander P.R. Bredenkamp, PMM - it was decided to change the name of the SA Naval Headquarters Unit and bring it into line with the naval custom that shore establishments bear a ship's name. So on 20 February 1981 at a colourful ceremony in the heart of Pretoria, the then Chief of the Navy, Vice Admiral R.A. Edwards, SSA, SM, handed over the telescope of command to Commander P.R. Bredenkamp, thereby charging him with command of the SA Naval Headquarters Unit under the new name SAS IMMORTELLE - a name steeped in history in the annals of the SA Navy ${ }^{1}$ of which the Naval Mess forms an intricate part. So let us trace the history of this Section of the 'flagship' - a hotel which is part of Pretoria.

\section{Early History and Construction of the Hotel}

On 18th June 1898, Mrs A.C.E. Ziervogel sold erven 591, 592, 598 and 599, which had been surveyed by F.S. Watermeyer in May 1898, to the Estate of the late William C. Faure for £2315. Mr William Nottingham, who had in turn bought erven 599 and 598 from the Estate of Faure, sold erf 599 to a certain Mr J.J. Kirkness on the 10th May 1906, for $£ 800$.

Mr Nottingham, who was a builder by profession, and had built the General Post Office building at Church square, later sold erf 598 to Mr J.J. Kirkness on the 4th Nov. 1923 for £4000. It was at this stage that the famous Union Hotel (then known as Union Mansions) was conceived by $\mathrm{Mr}$ J.J. Kirkness, director of the Groenkloof Brick, Tile and Pottery Factory Ltd.

The construction was started in 1923, with $\mathrm{Mr}$ J.J. Kirkness as contractor and completed in 1925 under supervision of Mr Alex Grand, who later became a Provincial Councillor in the Transvaal Provincial Administration. Mr Kirkness was also the contractor to the old Government House and renowned throughout the country for his fine building construction and brickworks.

The architect was Dr Gordon Leith (A.R.I.B.A.) of Johannesburg, who was a protege of the famous Sir Herbert Baker. Dr Leith was one of the codesigners of the Union Buildings and was greatly influenced by Sir Herbert Baker's admiration for the Roman and Greek architectural building art. Gordon Leith designed the Barclays Bank building on Church square, where his ability to maintain Bakers' influence and standard was proved beyond doubt.

The hotel design incorporated two-room flats and suites. In 1930 an extension containing a bar and accommodation facilities was added. The bricks in the building were $8^{\prime \prime} \times 21 / 2^{\prime \prime}$ and the construction was of the highest order. Uncertainty exists about the date the hotel's name was changed from Union Mansions to Union Hotel, but it is thought to be around 1930 .

The building was financed by J.J. Kirkness and William Millar as directors of Union Mansions Limited incorporated on 26th May 1924, who purchased the erven from J.J. Kirkness for $£ 32500$ on the 27th May 1924. The original two directors were later joined by Messrs T.G. Kirkness, J.N. Kirkness and Miss J.N. Gilchrist as shareholders.

\section{Life at the Hotel}

The Hotel's first manager, whose name is unknown was succeeded by Mr A.L. Nixon in 1928. Mr Nixon had been in control of the officers 


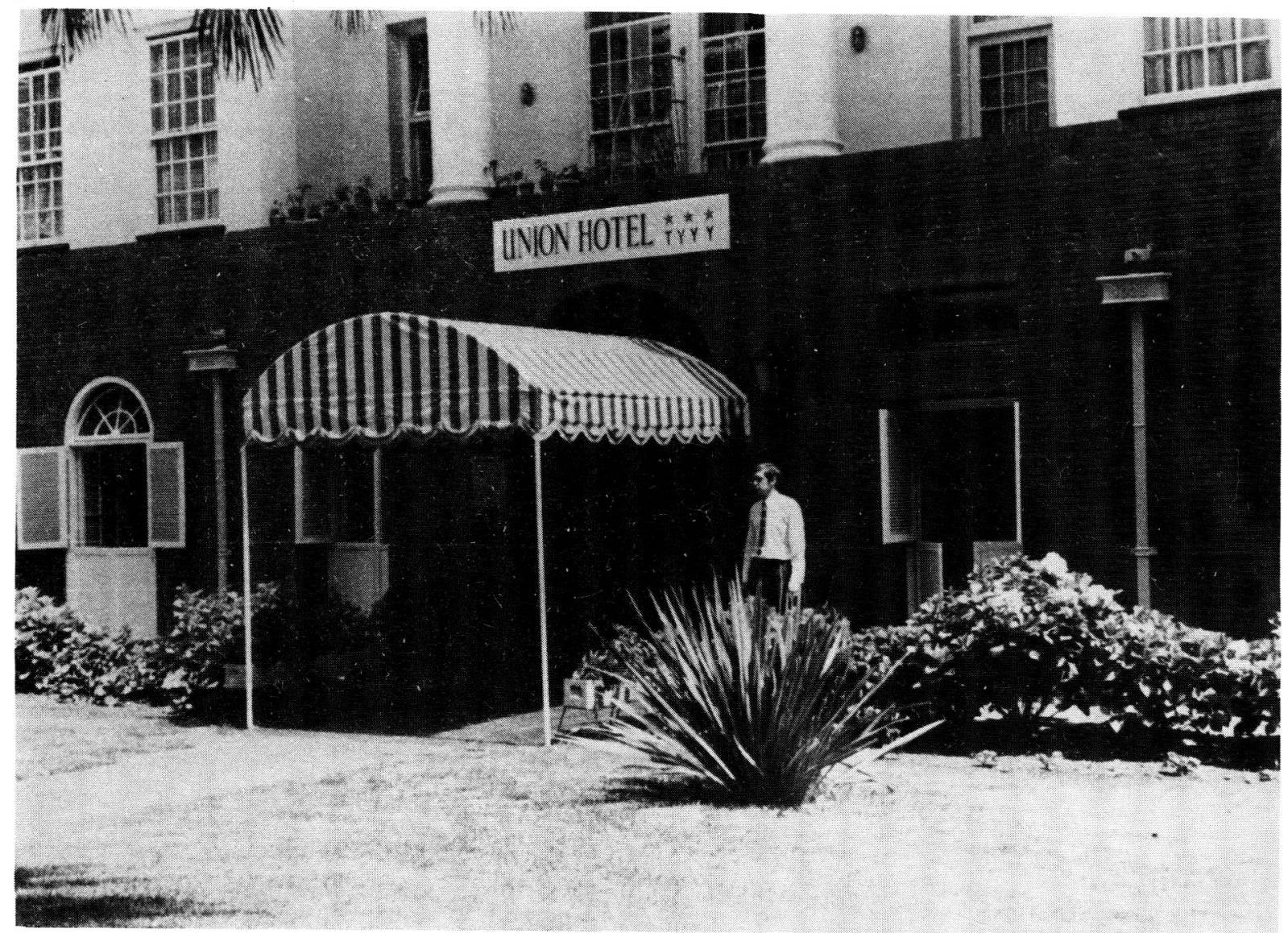

The Union Hotel

messes in the famous garrison towns of Aldershot, Woolwich and Colchester, before he moved to South Africa in 1919. Mr Nixon was replaced in July 1938 by the assistant manager, Mr P. Herbst, a South West African. The Chairman of the Company, Mr J.J. Kirkness passed away in June 1939. The same month, his son, Mr T.G. Kirkness was elected chairman of the Board and of the Company.

In June 1940, due to the 'unfortunate international situation, 'the Company dispensed with the services of $\mathrm{Mr} \& \mathrm{Mrs}$ Herbst. A new manager $\mathrm{Mr}$ L.D. Vynne was appointed in July 1940 at a salary of $£ 50$ per month, plus free board, lodging, laundry and 14 days leave per annum. All previous managers had similar salaries and fringe benefits.

At this point in time the flats were leased monthly at $£ 37.10$ per month for two persons or $£ 45$ per month for three persons, all meals inclusive. The amount of meals served averaged between 5000-7000 meals monthly, depending on the number of functions held. The Hotel charged £1 per month for parking and 10/-for cleaning each car. Casual visitors were charged $15 /-$ to $22 / 6$ d per day, according to the accommodation supplied

About half the accommodation was reserved for casual visitors and the rest for permanent residence. Twenty pounds a year was spent on advertisements in various newspapers and publications such as The Star, Cape Times, Caledonian and the Public Servant. The latter enticed many a diplomat in transit to the Hotel, which led to the Hotel being known as the 'diplomats' home.

Many dances were held in the Ballroom of the Hotel, the floor being well sprung, and ideal for dances. In fact during the construction of the ballroom, a worker discovered damp salt around some of the springs and, in consequence, the springs started rusting. In 1942 a person was charged 4/- entrance fee to be entertained by Michaels Rhythm Band.

The fact that it was an expensive Hotel did not refrain the people from enjoying the superb accommodation and dances held at the Hotel.

During the war, prices of foodstuffs and other 
commodities essential to the running of the Hotel', increased substantially, and the Hotel became a financial burden. Owing to shipping difficulties, some of the more popular lines in whiskey, became very scarce and authority was given to the manager to lay in a stock of whiskey to about £1000. An incredible amount in those days, which was later increased even further, when all distillation in Scotland stopped.

\section{Change of ownership}

The financial burden became too great and on the 13th March 1942, the Board of Directors of Union Hotel Ltd sold the hotel to Messrs Samuel Gavronsky and Percival Hirch Harris for the sum of $£ 65,000$ of which $£ 23,000$ was paid in cash and the balance in forty-two annual instalments.

Mr Vynne was retained as hotel manager and his salary increased to £65 per month plus £3 per month 'locomotion' allowance. In March $1944 \mathrm{Mr}$ L.D. Vynne was replaced by Mr. A.F. Quirk.

The Second World War ended in 1945 and in 1948 the country went to the polls. Gen Smuts was defeated and the National Party came to power with Dr D.F. Malan as leader. Dr Malan travelled to Pretoria where he stayed in the Union Hotel till 2nd June 1948. It was in the Union Hotel that the composition of the new cabinet was decided upon and appointed, to be later sworn in by the Governor General on the 4th June 1948.

On September 20, 1951, Mr N.V. Roberts, a Springbok clay pigeon marksman, was appointed manager, with Mrs Roberts as bookkeeper. They had a combined salary of $£ 80$ per month plus an entertainment allowance of $£ 15$.

The Company's name was changed on 23rd July 1953 to Union Hotels (Proprietry) Ltd. In September 1956, Mr Gavronsky and Mr Harris were at loggerheads and had reached a deadlock. After a lengthy discussion it was decided that $\mathrm{Mr} \mathrm{Har-}$ ris would purchase the Natal interests, i.e. the shareholdings in Balmoral Holding (Pty) Ltd, Metropole Hotels (Pty) Ltd and Union Hotel Properties (Pty) Ltd. The partnership was dissolved and Mr Gavronsky became the only director of the Union Hotel.

The east wing of the Hotel was completed in 1959 which included an a la carte Restaurant and Grill Room, called the Protea Room. This was opened in July 1959 by the Administrator of the Transvaal, Mr H.F. Odendaal. Today it serves as the Senior and Junior Rating's Mess.

It was in the east wing at Norman's (Roberts) Bar that the so-called 'Van der Merwe' joke 'originated.' The young architects who designed the wing placed a supporting column in the middle of the private bar counter. The building foreman's name was Van der Merwe and he used to hang his coat on a nail in the column. Anybody looking for Van der Merwe would wait at the column till he appeared

This column proved a bit of a nuisance once the wing was completed, but the name stuck to the column and anybody talking nonsense was sent to talk to Van der Merwe.

In 1965 Mr Gavronsky passed away and Mrs G. Posel and Dr H. Suzman, M.P., Houghton, his two daughters, became the Directors of Union Hotels (Pty) Ltd.

In March $1974 \mathrm{Mr}$ and Mrs N.V. Roberts retired and in due course Mr J.D. Hamilton was appointed manager, with Mr Roberts joining Mrs Posel and Dr Suzman as a director of the Company.

On 2nd January 1979, the Department of Community Development purchased the Hotel on behalf of the South African Navy for R1050 000,00. It was officially opened, as a Naval Mess, on Friday 24 August 1979 by the then Chief of the Navy, Vice-admiral J.C. Walters, SD, SM.

\section{Famous Visitors}

On 24th March 1936 Lord and Lady Baden-Powell were some of the first VIP guests to book in at the Union Hotel.

The Union Hotel was the first establishment in Pretoria at which black VIP's stayed. The most popular suites amongst the VIP's being suite no's 25,23 and 14

When Mr Dag Hammarskjöld visited South Africa in 1962 as UN Secretary General, to study South Africa's racial policies, he stayed in the Union. A special suite was fitted out for him with Italian antiques and decorated with paintings by South African artists. Suite no 14 cost nearly £2000 to redecorate and after his death in an aircraft crash, it was named after him. 


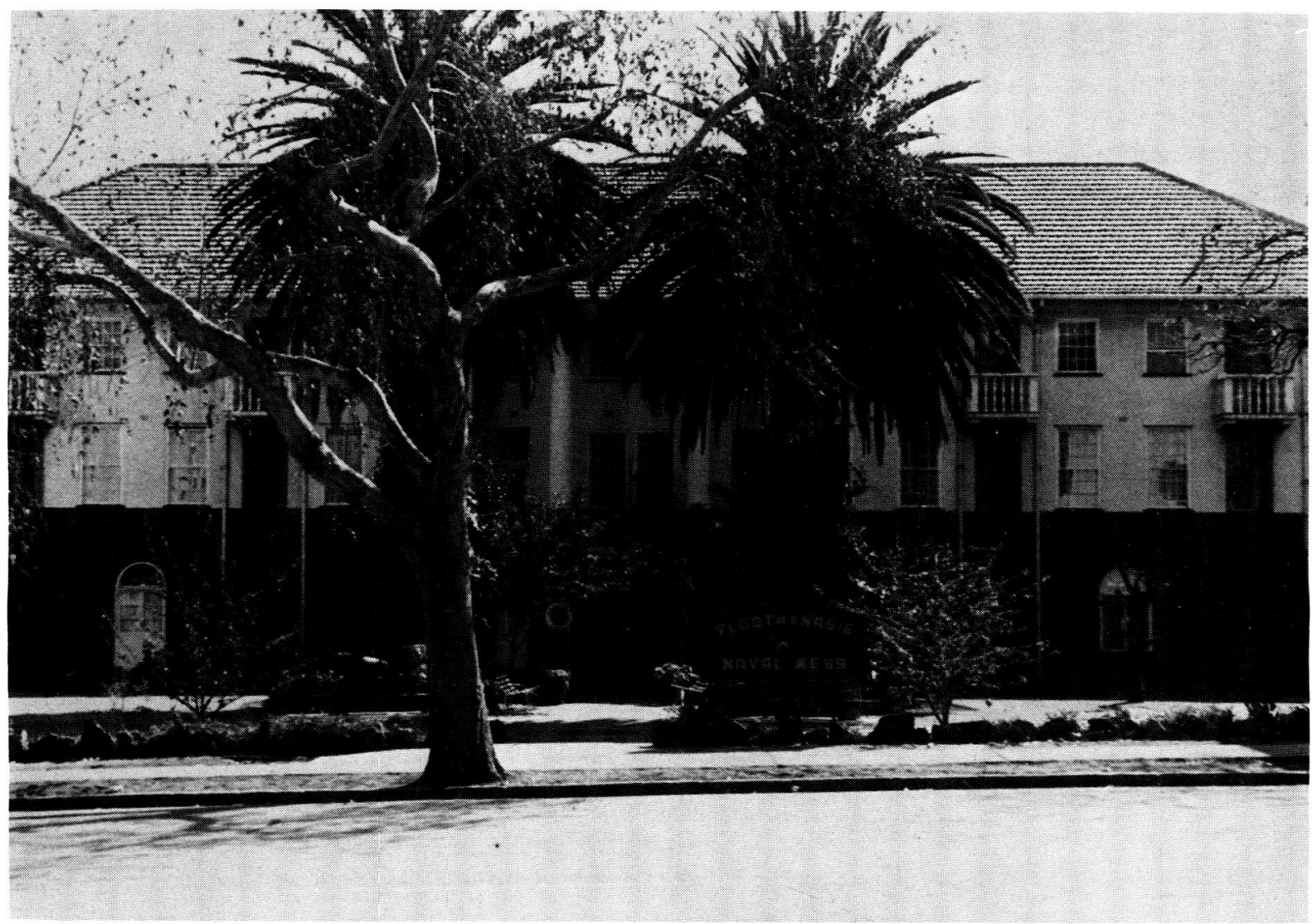

The Union Hotel was officially opened as a Naval Mess on 24 August 1979

Dr Carpio and his mission regarding the SWA question, also stayed at the Hotel. Incidentally his coffee was not 'poisoned' in the Union Hotel as is thought, but in SWA.

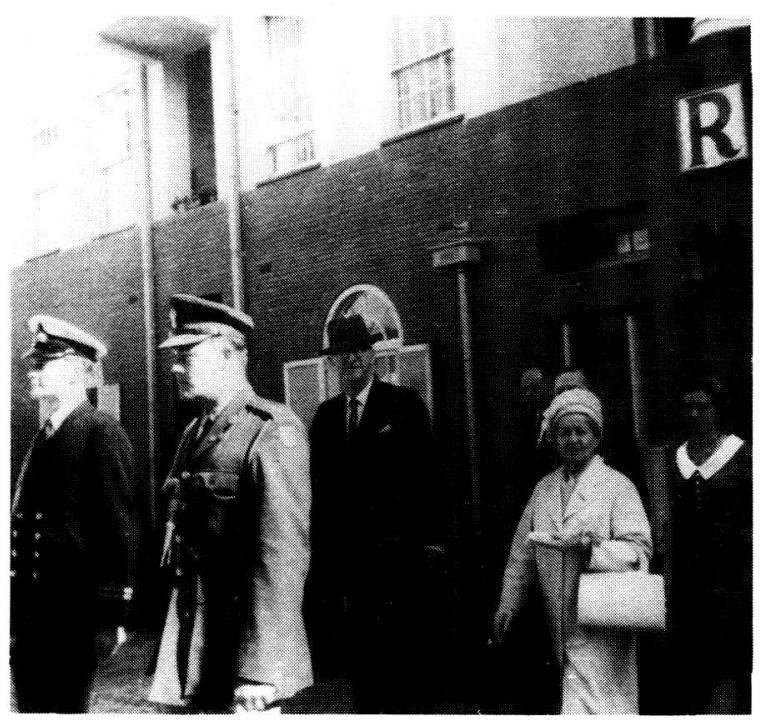

Distinguished guests, which included the former late State President C.R. Swart and his wife, as well as many other dignitaries, were amongst those to visit this remarkable building
While on short visits to Pretoria, as Governor General and State President, the late Pres. C.R. Swart stayed in the Union - in fact a long bed was specially made for him. The late Presidents J. Fouche and N. Diederich on occasions stayed in the Hotel. Pres B.J. Vorster as Prime Minister of South Africa booked in at the Union, as did the Prime Minister Mr P.W. Botha, when he was Minister of Defence.

Dr Dönges, when President elect and the President's Residence was being redecorated, was a guest of the Union Hotel.

Other regular guests were former Rhodesian Prime Ministers, Sir Roy Welensky and Ian Smith.

The Hotel was also the staying point of the Greyhounds (the Queen's messengers). Peter Townsend, who was romantically linked with Princess Margaret, stayed here, incognito, while on safari in South Africa.

The very first Provincial rugby team to stay at the Union was the Free State side (on 19th May 1939). After the War every International rugby and cricket side stayed at the Union. 
Today the Hotel is run as a Naval Mess for Officers, Warrant Officers, Senior and Junior ratings. This Mess, the living quarters for the ship's company of SAS IMMORTELLE is run on Navy lines. You walk along the 'deck', between the 'bulkhead', make your food in the 'galley' and sleep in 'cabins'.

Accommodation is provided for 200 ship's company and the victuals for the Officers, Warrant Officers, Chiefs and Petty Officers are prepared in the same galley. Under the management of Warrant Officer 1 W.E. Quinn PMD with his staff of 70 personnel, this mess remains shipshape at all times. ${ }^{2}$

Since its inception as a naval mess - 'She' - (a Ship is always known as a 'She') has catered for numerous functions for Chief of the Navy including state functions for the State President. Many a night the Dining Hall echoes to the sounds of the traditional mess dinners - carrying on a naval tradition which goes back to the days of sail.

* $S / L t$ J.D. Bredenkamp BA, is attached to the Military Information Bureau of the SADF

\section{Acknowledgements}

Dr H. Suzman MP

Cdr P.R. Bredenkamp, PMM

WO 1 W.E. Quinn PMD

Mrs G. Posel

Mrs B. Roberts

$\mathrm{Mr}$ D. Ochst

$\mathrm{Mr}$ J.D. Hamilton

Mr J.N. Kirkness

Miss J. Wierenga

Pretoria News

Minutes of Meetings held by Directors of Union Hotel Ltd

\section{Footnotes}

1. SAS IMMORTELLE, 20.2.83, a Naval HQ publication, p6. 2. Paratus: 15 April 1981. 